\title{
Knowledge of nursing students on the teaching-learning Systematization of Nursing Care
}

\author{
Conhecimento de acadêmicos de enfermagem sobre o ensino-aprendizagem da \\ Sistematização da Assistência de Enfermagem
}

Yara Nayá Lopes Andrade ${ }^{1}$, Elielza Guerreiro Menezes², Mara Julyete Arraes Jardim ${ }^{1}$, Jéssica Sâmia Silva Tôrres Ribeiro $^{1}$, Rodson Glauber Ribeiro Chaves ${ }^{1}$, Isaura Letícia Tavares Palmeira Rolim ${ }^{1}$

Objective: to analyze the knowledge of nursing students about the teaching-learning process of the Systematization of Nursing Care. Methods: this is a cross-sectional analytical research type, carried out with 111 students of the Nursing undergraduate course through a form. The calculation of the statistical frequencies and percentages was performed for the analysis. Results: $42.0 \%$ reported the use of traditionalist teaching methodology. $54.9 \%$ consider that the greatest difficulty was to relate theory and practice. $34.3 \%$ reported the case of partial lack of interest of students. 33.3\% indicated methodological divergence of teachers. Conclusion: the main difficulty of the academics surveyed in the teaching-learning process occurred by the gap between the theoretical knowledge and practical applicability, together with the form of predominantly traditionalist education.

Descriptors: Nursing; Nursing Process; Teaching.

Objetivo: analisar o conhecimento de acadêmicos de Enfermagem acerca do processo ensino-aprendizagem da Sistematização da Assistência de Enfermagem. Métodos: pesquisa do tipo analítico transversal, realizada com 111 discentes do curso de graduação em Enfermagem, por meio de um formulário. Para análise, foi realizado cálculo das frequências e percentuais estatísticos. Resultados: $42,0 \%$ relataram utilização de metodologia de ensino tradicionalista. 54,9\% consideram que a maior dificuldade estava em relacionar teoria e prática. 34,3\% relataram se tratar de desinteresse parcial dos discentes. 33,3\% apontaram divergência metodológica dos docentes. Conclusão: a principal dificuldade dos acadêmicos pesquisados no processo de ensino-aprendizagem ocorria pela lacuna existente entre o conhecimento teórico e a aplicabilidade prática, juntamente com a forma de ensino predominantemente tradicionalista.

Descritores: Enfermagem; Processos de Enfermagem; Ensino.

\footnotetext{
${ }^{1}$ Universidade Federal do Maranhão. São Luís, MA, Brazil.

${ }^{2}$ Universidade do Estado do Amazonas. Manaus, AM, Brazil.

Corresponding author: Yara Nayá Lopes Andrade

Avenida Babaçulandia, 679. Bairro Vila Lobão, CEP: 65910-000. Imperatriz, MA, Brazil. E-mail: yara_naya@hotmail.com
} 


\section{Introduction}

The Systematization of Nursing Care is defined as a private activity of nurses where there is the organization of the nursing teamwork, becoming a safer and systematic care for the patients. The methodological tool that directs the patient nursing care for the applicability of systematization of nursing care is the nursing process that seeks to achieve the quality of a fully paid and holistic patient care through its implementation and, consequently, greater visibility of the profession ${ }^{(1)}$.

The theoretical knowledge of the systematization of nursing care must be applied to practice through the implementation of the Nursing Process and must be directed by a Nursing theory chosen by the nurse, according to the profile of the patient, making satisfactory interventions to ensure quality of care provided to patients within the health services, whether public or private ${ }^{(1-2)}$.

The dimensions basing the Nursing Process are defined as follows: purpose, organization, and properties. It aims to provide a service capable of meeting the basic human needs in a comprehensive and individualized way for each patient, family, and community, and the relationship between the main focus should be prioritized and the nurse. The organization relies on the evaluation of the five stages of the process and its complexities: data collection or nursing history (anamnesis and physical examination), Nursing diagnosis, Nursing planning, implementation of care and nursing evaluation. The properties should be: deliberate, methodical or systematic, active or dynamic, interactive, flexible and based on theory, also known as the Nursing Theories ${ }^{(3)}$.

Reinforcing the importance and necessity of the Systematization of Nursing Care, the Resolution of the Federal Council of Nursing determines that the implementation of the Systematization of Nursing Care must necessarily occur in all Brazilian health institutions, both public and private, being formally registered in the medical records of patients containing all the steps of the Nursing Process ${ }^{(4-5)}$.

However, it is necessary that while being a nursing student, the professional develops skills and abilities that allow the execution of the five steps constituting the working tool of the process Nursing to associate the theoretical knowledge to the practical reality of the Systematization of Nursing Care: data collection or nursing history, Nursing diagnosis, Nursing Planning, Implementation of care and Evaluation ${ }^{(6)}$.

Regarding this subject, it was observed that most Nursing students do not develop the Systematization of Nursing Care in everyday academic practice in health institutions where they perform the assistance during mandatory practical activities required by the course, doing them just as a fulfillment of mandatory task by the institution ${ }^{(6)}$.

Thus, these claims showed that the difficulties for the applicability of the Systematization of Nursing Care may arise from the beginning of the course, when there is methodological divergence, by teachers in the standardization of education given ${ }^{(7)}$.

This topic, based on bibliographic references used for this study opens up a range of possible responses, needing to define some questions to be answered by the students during the research: Are the knowledge acquired on the Systematization of Nursing Care in theory classes applied in the practical field? What is the teaching methodology used by teachers in the process of teaching and learning Systematization? What are the perceptions of students about the main difficulties faced in carrying out the Systematization of Nursing Care? What gaps in the teaching-learning process and applicability of the Systematization of Nursing Care?

For these reasons, the investigation of this issue is justified within the local context with the main focus on analyzing the perceptions of nursing students from the Amazonas State University, Brazil about the teaching-learning process of the Systematization of Nursing Care. The study clarifies the causes that contribute to the students still in college not applying 
the holistic and efficient assistance, related to insufficient knowledge about the Systematization of Nursing Care or a methodological gap related to the theoretical and practical teaching.

The aim of the study was to analyze the knowledge of nursing students about the teachinglearning process of the Systematization of Nursing Care.

\section{Methods}

This is an analytical cross-sectional study. The study population was composed of students from the $4^{\text {th }}$ period of the Nursing Undergraduate course because it is the first time the teaching of systematization of nursing care and the nursing process is present, through the subject of Symptomatology and Nursing Semiotics, until the $8^{\text {th }}$ period, represented by the finalists of the course students and still holding theoretical classes at the institution since, from the $9^{\text {th }}$ period, they are just in practical areas.

The final sample included 111 students who met the following inclusion criteria: being a student older than 18 years old of both genders; a student who regularly attended the $4^{\text {th }}$ to the $8^{\text {th }}$ semester. Data collection took place between March and June 2014. For data collection, a semi-structured instrument (form) was used in two stages: the first stage was related to the characterization of academic study participants and the second stage was composed of specific objective questions of the theme.

For data analysis, the collected information was described and organized according to the similarity in a spreadsheet in Microsoft Office Excel 2010 program, and then, the information was worked initially by methods of descriptive analysis and subsequently the calculation of the frequency and statistical percentages was performed.

Statistical analysis of data was performed according to the absolute and relative distribution of variables $^{(8)}$. The results were presented descriptively and in tables, theoretically correlated with the strength of the studies conducted by the authors that support this research.

The study complied with the formal requirements contained in the national and international regulatory standards for research involving human beings.

\section{Results}

The results are neatly distributed as follows: characterization of study participants; specific research data concerning the opinion of students about the teaching-learning process of the Systematization of Nursing Care.

In the characterization by gender, there was a predominance of women with $70.0 \%$ of vacancies in the Nursing course, compared to $30.0 \%$ filled by men.

During the recognition of the prevalence related to age, there was a predominance of students between 18 and 23 years old (45.5\%) and later the students between 24 and 29 years old (32.7\%).

With regard to the characterization of the sample relative to coursed period, it can be seen that the distribution of students among the period 4, 5, 7 and 8 in the nursing course occurred in a proportional manner, with discrepancies only in the $6^{\text {th }}$ period represented almost a quarter of respondents students (24.5\%), higher than the other.

During the analysis of the applied form, the theoretical teachings on systematization are, in fact, applied to the practice area or training classes, observing that $20.0 \%$ of the students considered that this knowledge was always practiced, compared to $27.3 \%$ thinking that only occasionally, $40.9 \%$ said yes, but they are not carried out in line with the theory, 9.1\% thought that was frequently practiced and $2.7 \%$ who never have practiced.

On the methodology used by teachers in the 
teaching of systematization, $42.0 \%$ consider that the methodology was predominantly traditionalist, seen as fulfillment of institutional task, other $24.8 \%$ traditional but with problem-solving content, other 9.2\% reported be a practical methodology, fully problematical, and other $24.0 \%$ believed in a dialogic methodology, allowing academic interaction and teaching.

The students were asked about the main difficulties to the applicability of the Systematization of Nursing Care and 54.9\% considered that the greatest difficulty was linking the theory with practice, $18.6 \%$ believed that it would be the disbelief of nurses in the applicability of the Systematization, while $11.8 \%$ pointed that occurred due to failure to apply it in the practical area, $7.8 \%$ would be due to conflict of roles in support staff, and finally, $6.9 \%$ reported no clarification adequately during the lectures by teachers. Thus, a cross-table was held between periods, and their respective responses to questions to identify the problems prevailing in each period (Table 1).

When the students were asked about the level of interest in the learning of the Systematization in terms of its importance as a private action by nurses, $34.3 \%$ reported partial disinterest by learning difficulties, others $29.5 \%$ reported being associated with the deficiency of other key subjects for the construction of clinical reasoning of the Systematization of Nursing Care and Nursing Process as pathology, physiology, and semiotics, other $18.1 \%$ reported that a minority did not care and $10.5 \%$ reported noticeable lack of interest in learning the Systematization.

Similarly, it was necessary to adopt the same procedure to investigate the gaps, materialized in difficulty faced by students, about the learning process and practical applicability of the Systematization of Nursing Care.

Table 1 - Characterization of the main difficulties for applicability of existing systematization of Nursing Care

\begin{tabular}{|c|c|c|c|c|c|c|}
\hline Period & $\begin{array}{c}\text { Linking theory to } \\
\text { practice }\end{array}$ & $\begin{array}{l}\text { Disbelief in the } \\
\text { applicability }\end{array}$ & $\begin{array}{l}\text { No application in } \\
\text { the practical area }\end{array}$ & $\begin{array}{l}\text { Conflict of roles in the } \\
\text { nursing team }\end{array}$ & $\begin{array}{c}\text { Theoretical } \\
\text { explanation not } \\
\text { clarified }\end{array}$ & Total \\
\hline & n (\%) & n (\%) & n (\%) & n (\%) & n (\%) & n (\%) \\
\hline $4^{\text {rh }}$ & $10(47.6)$ & 3 (14.3) & $1(4.8)$ & $5(23.8)$ & $2(9.5)$ & $21(20.6)$ \\
\hline $5^{\text {th }}$ & $12(54.5)$ & 5 (22.7) & $5(22.7)$ & - & - & $22(21.6)$ \\
\hline $6^{\text {th }}$ & $15(65.2)$ & $3(13.0)$ & $3(13.0)$ & $1(4.3)$ & $1(4.3)$ & $23(22.5)$ \\
\hline $7^{\text {th }}$ & $9(56.3)$ & $3(18.8)$ & $2(12.5)$ & - & $2(12.5)$ & $16(15.7)$ \\
\hline $8^{\text {th }}$ & $10(50.0)$ & $5(25.0)$ & $1(5.0)$ & $2(10.0)$ & $2(10.0)$ & $20(19.6)$ \\
\hline Total & $56(273.6)$ & $19(93.8)$ & $12(58)$ & 8 (38.1) & 7 (36.3) & $102(100.0)$ \\
\hline
\end{tabular}


The most significant responses were considered methodological different disseminated by teachers, $33.3 \%$, followed by the lack of enforcement/association between theory and practice with $23.4 \%$. On the other hand, the academic disinterest was reported in $9.0 \%$ of responses and disability in basic subjects such as pathology, physiology, and semiotics with 8.1\%. A small minority reported that the workload for applicability of systematization in the practical area would be insufficient, with $7.2 \%$ of respondents, and $18.9 \%$ of the students did not answer the question.
Finishing the analysis and comparison of performing the variable period with the question, it can be concluded that the major difficulties of the students were facing the methodological differences of teachers cited in most of them, from the $6^{\text {th }}$ period. For students of the $4^{\text {th }}$ and $5^{\text {th }}$ periods, the gaps were well divided, between methodological differences, lack of interest of the academics, lack of execution/ association of theory and practice and also the deficiency of basic subjects (Table 2).

Table 2 - Characterization of existing gaps in the systematization of the teaching process reported by students

\begin{tabular}{|c|c|c|c|c|c|c|c|}
\hline Period & $\begin{array}{c}\text { Methodological } \\
\text { differences }\end{array}$ & $\begin{array}{l}\text { Disinterest of } \\
\text { the students }\end{array}$ & $\begin{array}{c}\text { Insufficient } \\
\text { hours }\end{array}$ & $\begin{array}{l}\text { Lack of execution/ } \\
\text { association of theory } \\
\text { and practice }\end{array}$ & $\begin{array}{l}\text { Deficiency } \\
\text { of basic } \\
\text { subjects }\end{array}$ & $\begin{array}{l}\text { Did not } \\
\text { answer }\end{array}$ & Total \\
\hline & n (\%) & n (\%) & n (\%) & n (\%) & n (\%) & n (\%) & n (\%) \\
\hline $4^{\text {th }}$ & $6(27.3)$ & $4(18.2)$ & $2(9.1)$ & 4 (18.2) & - & $6(27.3)$ & 22 (19.8) \\
\hline $5^{\text {th }}$ & $4(17.4)$ & $1(4.3)$ & $1(4.3)$ & $7(30.4)$ & $4(17.4)$ & $6(26.1)$ & $23(20.7)$ \\
\hline $6^{\text {th }}$ & $10(37.0)$ & $2(7.4)$ & $4(14.8)$ & 7 (25.9) & - & $4(14.8)$ & $27(24.3)$ \\
\hline $7^{\text {th }}$ & $9(47.4)$ & $1(5.3)$ & - & 3 (15.8) & 5 (26.3) & $1(5.3)$ & 19 (17.1) \\
\hline $8^{\text {th }}$ & $8(40.0)$ & $2(10.0)$ & $1(5.0)$ & $5(25.0)$ & - & $4(20.0)$ & $20(18.0)$ \\
\hline Total & 37 (169.1) & $10(45.2)$ & $8(33.2)$ & $26(115.3)$ & $9(43.7)$ & $21(93.5)$ & $111(100.0)$ \\
\hline
\end{tabular}

\section{Discussion}

Among the main limitations of this study, there were results not generalized because the study was held in a specific population of students from a public university in the city of Manaus, state of Amazonas, Brazil. In this way, it is suggested to conduct similar studies among undergraduate nursing students in other public and private institutions for the recognition and resolution of gaps in the Systematization of Nursing Care in the teaching-learning process, corroborating theoretical with practical applicability and standardization of education by teachers, as students understand the importance of the method, but they do not fully operate it in practice.
It is visible the fragmentation suffered between theoretical learning, and the development found in practice area, thus causing frustration in students along with disbelief reliability in the Systematization of Nursing Care and the Nursing Process ${ }^{(9)}$. Therefore, it may be seen that the process of teaching of the Systematization Nursing Care occurs in most of the cases, based on a primarily theoretical methodology than practice, hindering the exercise of the working tool $^{(6)}$.

Regarding the characterization of the responses of students in the methodology used by teachers in teaching the Systematization of Nursing Care, the 
vertically integrated and traditionalist methodology is one of the major difficulties experienced in the teaching of the Systematization. The method is referenced by using the expository teaching, often known as "bank method." This education form is where the teacher puts information passively and without teaching/ academic interaction, inducing a sense of revulsion of the students, resulting in a refusal by the approach to the Systematization of Nursing Care ${ }^{(7,9)}$.

Given this information, it is emphasized that teachers should be able to enter the formation of critical thinking and clinical judgment to the daily lives of students, guiding the formation of future nursing professionals. Thus, it is essential to the improvement and qualification of the teaching staff by using the Continuing Education within the institutions, consolidating the process of communication and education to become a more harmonious interaction between teachers and students ${ }^{(10)}$.

It was found the predominance of reports that the main difficulty was related mainly to the little association between theory and practice. Thus, other studies are similar with this result, noting that the main difficulties of academics to hold the Systematization of Nursing Care during practical activities may arise from unfamiliarity and little effective presence in the practice area and lack of simulation of situations experienced in reality to the applicability in the academic world, resulting in a gap of what is learned in theory and in fact, what it is developed in the practical area ${ }^{(11-12)}$.

The challenges involved directly in the development and implementation of the Systematization in the institutions are based as follows: unsatisfactory scientific theoretical knowledge, lack of theoretical association with the practice in the institutional area, the minimum number of nurses in health services, influencing on not the uniformed and organized development of process steps, generating conflict of roles, lack of theoretical domain to the development and systematization of nursing process or even little familiarity and involvement with it ${ }^{(9)}$.
The approach to the interest level of academics was held regarding the applicability of the Systematization of Nursing Care. Despite the students recognize the importance of the Systematization and the Nursing Process, most individuals reported that the process of teaching method of learning was a difficulty faced by most students, because of the degree of complexity, generating tension and partial detachment, resulting in feelings of frustration and disappointment for not using the systematization in health services, whose lack of interest in learning and applicability the method culminated in a permanent position of detachment during the academic experience ${ }^{(13-14)}$.

With this information, the adaptation and improvement of teaching techniques proposed by teachers become necessary, aiming to rescue the students of interest to the profession ${ }^{(12)}$.

Furthermore, it was possible to perform association with other studies found, reaching a consensus that strengthening the teaching of the Systematization of Nursing Care should be grown continuously, with just basic reformulations, such as making the training of teachers, aiming adequacy of uniform methodologies across subjects in all periods of graduation, avoiding the segregation of knowledge and the spread of the interest of students ${ }^{(11-12,15)}$.

The process performance requires the professional a consolidated scientific basis and based on the basic subjects, such as Physiology, Pathology, and Semiology, and the management skills of the units that are indispensable for building diagnostics and implementation of care, literary or theoretical domain, dexterity in the consolidation of the actions, fitness in the development of judgments and attitudes based on professional ethics and responsibility in taking care of other values are still built along the graduation ${ }^{(10)}$.

Knowing that the qualification of teachers is linked directly to the professional guidance and academic development for the future entry into the labor market, training of teachers becomes essential for designation of the emitted knowledge, as well 
as the delimitation of the theoretical tool to be implemented along the graduation and the insertion of new updates to the detriment of the Systematization and the Nursing Process must simulate the activities experienced in practical everyday life, along with the use of dialogic models and problem-solving methods that induce the formation of ideas and autonomy for resolution conflict ${ }^{(10-12,16)}$.

\section{Conclusion}

The operation of the Systematization in Nursing Care provides autonomy to nurses. Based on this and to analyzing the knowledge of nursing students about the teaching and learning of that thematic process, it was observed that the main difficulty encountered by students was the gap between the theoretical knowledge and practical applicability, along with the teaching methodology predominantly traditionalist by teachers. Thus, it is necessary to implement educational strategies capable of stimulating teachers in implementing the Systematization of Nursing Care and standardization of education.

It was observed that the study participants understood the importance of that issue and the need to be part of this process of expansion and consolidation of the operation of the systematization of nursing care. However, the learning process of systematization is a difficulty faced by most students, because of their degree of complexity, generating tension and disinterest caused by the inapplicability and/or partial use of this tool in health care, culminating in a standing posture distance during the academic experience.

\section{Acknowledgement}

To the Research Foundation for the Amazonas State, the support through for the Program of Support for Scientific Initiation of Amazonas, under Case no $251 / 2014$.

\section{Collaborations}

Andrade YNL and Menezes EG contributed to the project, collection, organization, and interpretation of data. Rolim ILTP contributed in the writing and relevant and critical analysis of the content. Jardim MJA, Ribeiro JSST, and Chaves RGR contributed in writing the article and final approval of the version to be published.

\section{References}

1. Chaves LD. SAE: considerações teóricas e aplicabilidade. SãoPaulo: Martinari; 2009.

2. Silva JP, Garanhani ML, Guariente MHDM. Sistematização da assistência de enfermagem e o pensamento complexo na formação do enfermeiro: análise documental. Rev Gaúcha Enferm. 2014; 35(2):128-34.

3. Santos ADB, Oliveira KKD, Rosário SSD, Lira ALBC, Tourinho FSV, Santos VEP. Strategies for teaching learning process in nursing graduate and postgraduate nursing. J Res Fundam Care online [Internet]. 2014 [cited 2016 Mar. 20]; 6(3):121220. Available from: HTTP://www.seer.unirio. $\mathrm{br} /$ index.php/cuidad ofundamental/article/ view/1604/pdf_1380

4. Neco KKS, Costa RA, Feijão AR. Systematization of nursing care in health institutions in brazil: an integrative review. Rev Enferm UFPE on line [Internet] 2015 [cited 2016 Mar. 20]; 9(1):193200. Available from:http://www.revista.ufpe.br/ revistaenfermagem/index.php/revista/article/ viewArticle/6602

5. Rosenstock KIV, Soares MJGO, Santos SR, Ferreira ASM. Aspectos éticos no exercício da enfermagem: revisão integrativa da literatura. Cogitare Enferm. 2011; 16(4):727-33.

6. Medeiros AL, Santos SR, Cabral RWL. Sistematização da assistência de enfermagem na perspectiva dos enfermeiros: uma abordagem metodológica na teoria fundamentada. Rev Gaúcha Enferm. 2012; 33(3):174-81. 
7. Fontes WD, Leadebal ODC, Ferreira JA. Competências para aplicação do processo de enfermagem: auto-avaliação de discentes concluintes do curso de graduação. Rev Rene. 2010; 11(3):86-94.

8. Medronho RA, Bloch KV, Luiz RR, Werneck GL. Epidemiologia. São Paulo: Atheneu; 2008.

9. Silva EGC, Oliveira VC, Neves GBC, Guimarães TMR. Nurses' knowledge about Nursing Care Systematization: from theory to practice. Rev Esc Enferm USP. 2011; 45(6):1380-6.

10. Menezes SRT, Priel MR, Pereira L. Nurse's autonomy and vuknerability in the nursing assistance systematization practice. Rev Esc Enferm USP. 2011; 45(4):953-58.

11. Silva JP, Garanhani ML, Guariente MHDM. Systematization of nursing care in undergraduate training: the perspective of complex thinking. Rev Latino-Am Enfermagem. 2015; 23(1):59-66.

12. Silva CC, Gelbcke FL, Meirelles BNS, Arruda C, Goulart S, Souza AIJ. O ensino da Sistematização da Assistência na perspectiva de professores e alunos. Rev Eletr Enf [Internet]. 2011 [citado 2013 out. 20]; 13(2):174-81. Disponível em: http:// www.fen.ufg.br/revista/v13/n2/v13n2a03.htM
13. Soares MI, Resck ZMR, Terra FS, Camelo SHH. Systematization of nursing care: challenges and features to nurses in the care management. Esc Anna Nery. 2015; 19(1):47-53.

14. Soares MI, Resck ZMR, Terra FS, Camelo SHH. Sistematização da assistência de enfermagem: facilidades e desafios. Esc Anna Nery. 2015; 19(1):47-53.

15. Barlem JGT, Lunardi VL, Lunardi GL, Barlem ELD, Silveira RS, Vidal DAS. Burnout syndrome among undergraduate nursing students at a public university. Rev Latino-Am Enfermagem. 2014; 22(6):934-41.

16. Instituto Nacional de Estudos e Pesquisas Educacionais Anísio Teixeira (BR). Sinopses Resultados 2011 Educação Superior - Graduação [Internet]. 2011 [citado 2014 maio 3]. Disponível e m:http://portal.inep.gov.br/superiorcensosuperior-sinopse 